Estudios Constitucionales, Año 16, No 1, 2018 pp. 187-226

ISSN 07180195

Centro de Estudios Constitucionales de Chile Universidad de Talca

"Una reconstrucción dogmática de la inaplicabilidad por inconstitucionalidad"

Ricardo Salas Venegas

\title{
UNA RECONSTRUCCIÓN DOGMÁTICA DE LA INAPLICABILIDAD POR INCONSTITUCIONALIDAD LAS INAPLICABILIDADES PROPIA E IMPROPIA, LA LEGISLACIÓN NEGATIVA SINGULAR, EL CONTROL PREVENTIVO DE CONSTITUCIONALIDAD DE LAS SENTENCIAS Y LA EQUIDAD CONSTITUCIONAL*-**
}

\author{
A LEGAL RECONSTRUCTION OF WRIT OF NON-APPLICABILITY \\ PROPER AND IMPROPER WRITS OF NON-APPLICABILITY, \\ SINGULAR NEGATIVE LEGISLATION, PREVENTIVE JUDICIAL REVIEW OF \\ JUDICIAL DECISIONS AND CONSTITUCIONAL EQUITY
}

\author{
Ricardo Salas Venegas ${ }^{* * *}$ \\ Universidad de Valparaíso \\ rsalasvenegas@gmail.com
}

RESUMEN: En el artículo 93 No 6 de la constitución se consagran una acción de inaplicabilidad por inconstitucionalidad propia o concreta, en que se ejerce un control de constitucionalidad mixto, facultativo, preventivo, concreto, con efecto relativo y que tiene por objeto a las sentencias judiciales de tribunales ordinarios o especiales, y una acción de inaplicabilidad por inconstitucionalidad impropia o abstracta en que se ejerce un control de constitucionalidad concentrado, facultativo, represivo, abstracto, con efecto relativo y que tiene por objeto a los preceptos legales. En la primera el Tribunal Constitucional obra como juez correctivo de equidad constitucional; en la segunda, como legislador negativo singular.

\footnotetext{
* Artículo recibido el 24 de marzo de 2017 y aprobado el 10 de enero de 2018.

${ }^{*}$ La idea central de este artículo fue expuesta en un capítulo de la tesis doctoral inédita del autor "Fundamentos neotomistas para una teoría de la legislación" dedicado a distinguir los fundamentos de la legislación abstracta de los de la jurisdicción concreta, dirigida por el Prof. Agustín Squella, y defendida en la Universidad de Chile ante un tribunal integrado por los profesores Davor Harasic, Fernando Atria, Juan Pablo Mañalich (todos, U. de Chile), Marcelo Alegre (U. de Buenos Aires) y Cristóbal Orrego (PUC), a quienes agradezco sus constructivas observaciones. Agradezco también los comentarios sobre otra versión de este texto, recibidos del profesor Alan Bronfman en un seminario en la Universidad de Valparaíso. Todos los errores que se contengan son, sin embargo, de exclusiva responsabilidad del autor. Finalmente, el autor agradece la colaboración de sus exalumnos don Joaquín Barahona, don Esteban Contador, doña Aileen Espinoza y don Francisco Zepeda.

*** Doctor en Derecho (Universidad de Chile). Profesor de la Escuela de Derecho de la Universidad de Valparaíso. Investigador CIFDE.
} 
ABSTRACT: The article $93 N^{\circ} 6$ of the Constitution contents a proper writ of non-applicability, in which the judicial review is mixt, facultative, preventive, concrete, with relative effect and its object is a judicial decision of ordinary and extraordinary courts and a improper writ of non-applicability, in which the judicial review is concentrate, facultative, represive, abstract with relative effect and its object is a precept of a statute. In the first, Constitutional Court act as a corrective judge of constitutional equity; in the second, as a singular negative legislator.

PALABRAS CLAVE: Control de constitucionalidad, inaplicabilidad, inaplicabilidad propia, inaplicabilidad impropia, inconstitucionalidad, equidad, equidad constitucional, legislador negativo, control preventivo, control preventivo de sentencias.

KEYWORDS: Judicial review, non-inapplicability, proper writ of non-applicability, improper writ of non-applicability, unconstitutional norms, equity, constitutional equity, negative legislator, preventive judicial review, preventive judicial review of judicial decisions.

\section{INTRODUCCIÓN}

A partir de los enunciados normativos contenidos y expresados en las diversas fuentes del derecho, la dogmática jurídica crea paulatinamente un sistema jurídico que aspira a una coherencia de la que usualmente carece el ordenamiento considerado puramente como tal. La dogmática constitucional hace lo propio con las normas que integran el bloque de constitucionalidad, tanto cuando las considera globalmente como cuando atiende a una parte de dichas normas de tal manera unidas entre sí que configuran una institución identificable perfectamente por separado. Uno de los tópicos de la ciencia del derecho constitucional es la localización, la interpretación, la sistematización y la justificación de las normas reguladoras del control de constitucionalidad en general y del control de constitucionalidad de las leyes en particular. La doctrina constitucional chilena se ha venido afanando desde el año 2005 en darle un sentido adecuado a los textos que en nuestra Carta Fundamental y en la Ley Orgánica Constitucional del Tribunal Constitucional se referirían al control represivo de constitucionalidad de la leyes, el cual parece articulado sobre la base de dos acciones, la acción de inaplicabilidad por inconstitucionalidad y la acción de inconstitucionalidad, respectivamente descritas en los artículos 93 No 6 y 93 No 7 de la constitución. Con todo, el intento de sistematizar ambas disposiciones no ha dado los frutos esperados, por lo que se hace necesario leer nuevamente ambos textos con el fin de proponer, desde idénticos textos, una nueva sistematización para la clase de control de constitucionalidad previsto en ellos ${ }^{1}$.

${ }^{1}$ Una temprana visión panorámica de lo que aquí se llamará "doctrina estándar" puede hallarse en PICA, Rodrigo (2010). 
Varios de los problemas dogmáticos que suscita el artículo 93 № 6 de la constitución política derivan de la creencia en que por la acción, el proceso, el requerimiento, el incidente o la cuestión ${ }^{2}$ de inaplicabilidad por inconstitucionalidad, aparentemente contenidos en esta disposición, el Tribunal Constitucional practicaría un control de constitucionalidad concentrado, facultativo, represivo, concreto y con efecto relativo sobre preceptos legales ${ }^{3}$.

La verdad, sin embargo, es que esta caracterización de la clase de control allí regulado es fruto de la confusión en una sola -en la acción de inaplicabilidad por inconstitucionalidad- de las que, en realidad, son dos acciones que se hallan contenidas en el mismo enunciado constitucional y que pueden ser denominadas "acción de inaplicabilidad por inconstitucionalidad propia o concreta" y "acción de inaplicabilidad por inconstitucionalidad impropia o abstracta", las cuales, en tanto que acciones, se distinguen entre sí porque responden a una causa de pedir diferente, tienen un objeto diferente, se promueven oportunidades diferentes y cumplen funciones diferentes. Al distinguirlas, las características que se atribuían en bloque a aquella pretendidamente única acción de inaplicabilidad por inconstitucionalidad quedan redistribuidas entre estas dos diferentes acciones de inaplicabilidad por inconstitucionalidad y el signo con que se las adjudica a una de ellas queda invertido en la otra.

Así, si se califica al control de la pretendidamente única acción de inaplicabilidad por inconstitucionalidad como facultativo o eventual, como concreto y con efecto relativo o inter partes es porque tales son las características de la inaplicabilidad propia o concreta. Si al mencionado control también se lo califica como concentrado y represivo, es porque estos rasgos caracterizan la inaplicabilidad impropia o abstracta, la cual, adicionalmente y como la primera, también es facultativa o eventual y produce un idéntico efecto relativo o inter partes. Sin embargo, la naturaleza mixta y preventiva que adquiere el control cuando se declara una inaplicabilidad propia queda tan oscurecida como el carácter abstracto que posee en la inaplicabilidad impropia. Y del mismo modo queda encubierto el hecho de que en la inaplicabilidad propia el objeto sobre el cual recae el control no es un precepto legal sino una sentencia judicial.

\footnotetext{
2 Todas estas denominaciones ha recibido lo que en este trabajo se tratará preferentemente como una acción. El Tribunal Constitucional, aunque utiliza todas ellas, ha ido uniformando la denominación de «requerimiento» de inaplicabilidad.

3 Por todos, véase: ZúnígA (2010) pp. 18 y ss.
} 
La acción de inaplicabilidad por inconstitucionalidad propia da lugar a un control de constitucionalidad mixto, facultativo o eventual, preventivo, concreto y con efecto relativo o inter partes, que tiene por objeto a las sentencias judiciales, mientras que, mediante la acción de inaplicabilidad por inconstitucionalidad impropia, se practica, en cambio, un control de constitucionalidad concentrado, facultativo o eventual, represivo, abstracto y con efecto relativo o inter partes sobre preceptos legales. Lo que las hace semejantes es su alcance, pues ambas tienen efecto relativo, y su facultatividad o eventualidad, pero, como se ve, difieren en todo lo demás.

El Tribunal Constitucional que conoce de ellas actúa en un caso (en el de la acción de inaplicabilidad por inconstitucionalidad propia) como un juez de equidad constitucional correctiva y en el otro (en el de la acción de inaplicabilidad por inconstitucionalidad impropia) como legislador negativo singular. En razón de esto, la acción de inaplicabilidad por inconstitucionalidad impropia tiene, en su núcleo, según el modelo de justificación al que queda sometida la sentencia, más en común con la acción de inconstitucionalidad (la del artículo 93 № 7 , en que el Tribunal Constitucional actúa como legislador negativo general) que con la acción de inaplicabilidad por inconstitucionalidad propia o concreta.

Por eso, cuando la constitución exige para la declaración de inconstitucionalidad de un precepto legal el que éste haya sido ya declarado inaplicable, hay que entender que este requisito se refiere solamente a la inaplicabilidad impropia, lo que significa que el Tribunal Constitucional puede $-\mathrm{y}$ debe- declarar inconstitucional un precepto legal en ejercicio de sus potestades como legislador negativo general sólo cuando este tribunal haya obrado ya como legislador negativo singular sobre el mismo precepto, y nunca cuando lo haya hecho como juez de equidad constitucional correctiva para una sentencia, y algo semejante acontece cuando la ley declara inadmisible la acción de inaplicabilidad deducida contra un precepto antes ya declarado constitucional, en virtud de los denominados "sello de constitucionalidad" o "cosa juzgada constitucional"4.

A estas conclusiones puede llegarse si se emprende una reconstrucción dogmática de los enunciados contenidos en los numerales 6 y 7 del artículo 93 de la constitución y de aquellos otros enunciados constitucionales y legales que los desarrollan. La doctrina estándar hasta ahora había pretendido realizar un estudio aislado y por separado de los numerales 6 y 7 del artículo 93 para luego pronun-

${ }^{4}$ Cfr. Verdugo, Sergio (2009), pp. 57 y ss. 
ciarse sobre si la interpretación que daba a uno era compatible con la que le daban al otro. Su empeño era vano porque de entrada impedía mostrar que todos estos enunciados, desde su autonomía semántica, es decir, con independencia de las dispares e indeterminables intenciones subjetivas de quienes intervinieron en su redacción final, configuran un subsistema unitario y coherente de tres acciones constitucionales que están referidas desde el inicio las unas a las otras.

\section{LA ACCIÓN DE INAPLICABILIDAD POR INCONSTITUCIONALIDAD IMPROPIA O ABSTRACTA}

Tras la reforma de la constitución en el año 2005, fue gestándose paulatinamente una doctrina estándar acerca del modelo de control de constitucionalidad que quedaba fijado en las nuevas atribuciones otorgadas al Tribunal Constitucional. La estrategia seguida por los constitucionalistas para conferir un sentido a los numerales 6 y 7 del artículo 93 fue la de comparar por separado su contenido con el del artículo 80 que por esta reforma quedaba derogado, lo que les llevó a una errónea interpretación de estas nuevas disposiciones constitucionales, pues el resultado inevitable de este proceder, entre otros aspectos, era la idea de que el contenido del antiguo artículo 80 quedaba totalmente reemplazado por el del actual numeral 6 del artículo 93, mientras que, en el numeral 7, se añadía una acción del todo novedosa 5 .

Sin embargo, si se miran ambos numerales como un subsistema unitario y coherente y luego se lo compara con el antiguo artículo 80 , se verá que la reforma de 2005 recogió buena parte de lo que fue el recurso de inaplicabilidad por inconstitucionalidad previsto en el ya derogado artículo 80 del texto original de la actual constitución política, el que, a su vez, había revalidado el recurso de inaplicabilidad consagrado en el artículo 86 , inciso $2^{\circ}$, de la constitución de 1925. Se trata de una acción veterana de nuestra historia constitucional que, entonces, contra la extendida opinión de los constitucionalistas, pervive en el actual artículo 93 No 6 de la constitución con la misma configuración que tuvo cuando se hallaba hospedada en el artículo 80. Ésta es, así, una de las dos acciones previstas en este numeral, a la que conviene denominar "acción de inaplicabilidad por inconstitucionalidad impropia o abstracta” porque, bajo la apariencia de una mera inaplicabilidad concreta de carácter jurisdiccional, se halla una derecha inconstitucionalidad de control puramente abstracto de carácter legislativo.

5 Cfr. Nogueira, Humberto (2005), pp. 11 y ss. 
Por la acción de inaplicabilidad por inconstitucionalidad impropia el Tribunal Constitucional ejerce un control de constitucionalidad concentrado, facultativo o eventual, represivo, abstracto y con efecto relativo o inter partes sobre preceptos legales. El control es concentrado porque la inaplicabilidad puede ser declarada por el Tribunal Constitucional con exclusión de cualquier otro tribunal; es facultativo o eventual porque su práctica no está considerada por el ordenamiento como un requisito de validez formal de los preceptos legales y es represivo porque tiene lugar sólo una vez que el precepto impugnado ha entrado en vigencia. Nada de esto es novedoso, como tampoco lo es que se califique los efectos de este control como relativos o inter partes.

Pero es posible que haya quienes controviertan el carácter abstracto con que se califica aquí a la acción de inaplicabilidad impropia, aferrados a la idea de que con la reforma constitucional de 2005 se incorporaron a la constitución dos acciones en numerales diferentes, la de inaplicabilidad con carácter concreto en el artículo 93 No 6 y la de inconstitucionalidad con carácter abstracto en el artículo 93 No 7. Dirían ellos que caracterizar la acción del artículo 93 No 6 como un ejemplo de control abstracto es confundir la inaplicabilidad por inconstitucionalidad con la inconstitucionalidad, puesto que sólo mediante esta última se ejerce un control abstracto en virtud del cual, luego de un examen que revele su incompatibilidad lógica con alguna disposición constitucional, puede derogarse un precepto legal estimado inconstitucional.

La acción de inaplicabilidad, podrían ellos continuar, es siempre concreta porque lo que en ella se examina es si la aplicación de un precepto legal a un caso particular produce efectos inconstitucionales, con independencia de la constitucionalidad del precepto mismo, porque bien puede acontecer que un precepto legal que no colisione lógicamente con la constitución, de ser aplicado para decidir una particular gestión pendiente, terminaría produciendo una situación inconstitucional. A fin de cuentas, concluirían ellos, lo inconstitucional no es el precepto sino su interpretación para el caso concreto.

Quienes así opinan llevan una parte de razón porque su defensa del control concreto se asienta en que el artículo 93 No 6 de la constitución contempla efectivamente un control concreto en la acción de inaplicabilidad por inconstitucionalidad propia, que, como se verá en la sección siguiente, supone la validez abstracta del precepto cuya aplicación aparecería cuestionada. Pero su error es creer que todo el control que es posible realizar según el artículo 93 No 6 es un control concreto. Aislando este numeral, ellos pierden de vista que su conexión con el numeral siguiente (y con las disposiciones legales complementarias) en numerosas 
ocasiones permite y hasta exige utilizar esta misma acción de inaplicabilidad como vehículo procesal para el ejercicio de un control de constitucionalidad abstracto sobre preceptos legales, tal como ocurría con el antiguo recurso de inaplicabilidad por inconstitucionalidad. Efectivamente, esta disposición tiene un y sólo un contenido lingüístico, y, por ello, se cree que en ella puede estar contenida una y sólo una acción, pero se olvida que su conexión con otras disposiciones hacen nacer de ese único contenido lingüístico no una sino dos normas, que sustentan las dos acciones de inaplicabilidad aquí reseñadas.

Antes de referirse los trabajos preparatorios de la reforman de 2005, puede ser útil establecer a priori los grados crecientes de intensidad con que cabía intervenir el artículo 80 para reconstruir sobre esa base la historia de esta reforma, señalando las diversas alternativas posibles, para descubrir finalmente a cuál de estos grados pertenece el texto definitivamente aprobado. Estos grados de reforma avanzan desde el grado mínimo en que no se introduce modificación alguna hasta el grado máximo en que simplemente se deroga este artículo sin que nada quede de él. Considerando los binomios del control concreto y del control abstracto, por una parte, y del control con efectos particulares y el control con efectos generales, por la otra parte, los grados de intervención estarían reflejados en las alternativas siguientes: control abstracto con efectos particulares, control concreto con efectos particulares, control abstracto con efectos generales y control concreto con efectos generales.

Puede identificarse el control abstracto con efectos particulares con el grado mínimo de reforma si se prueba que tales características eran las propias del recurso de inaplicabilidad por inconstitucionalidad, lo que, por lo demás, es fácil sostener. En general, la Corte Suprema entendió siempre como su función la de comparar el contenido de un precepto legal con el contenido de un precepto constitucional, sin hacer cuestión de los hechos concretos sobre los que versaba la gestión pendiente en que ellos incidían, acogiendo o rechazando el recurso según si este examen puramente normativo mostrase o no una precisa antinomia ${ }^{6}$. La actitud de la Corte Suprema respondió siempre al tenor del artículo 80, por el cual se le señalaba que "podrá declarar inaplicable para esos casos particulares todo precepto legal contrario a la Constitución”, con lo cual, esta corte dejaba en claro

${ }^{6}$ Este modo canónico de entender la inaplicabilidad fue, aisladamente, sometido a crítica por Fernando Atria, aunque sin que consiguiera perfilar exactamente que buena parte de los problemas eran efecto de una identificación errónea del objeto de una verdadera inaplicabilidad, que es siempre una sentencia judicial. Cfr. Atria (2001), pp. 119 y ss. 
que el objeto del control era el precepto mismo, o sea, que lo inconstitucional era el precepto y no su aplicación. Si el contenido de la reforma del 2005 fue la mera traslación de esta competencia desde la Corte Suprema al Tribunal Constitucional, la reforma habría sido, en este sentido, una reforma mínima, puramente orgánica y para nada funcional. $Y$ así parecen entenderlo una doctrina minoritaria y buena parte de la jurisprudencia constitucional.

Pablo Rodríguez Grez defiende la idea de que "[n]o ha habido una transformación sustancial entre el recurso de inaplicabilidad que, hasta la reforma de 2005, conocía la Corte Suprema y el actual recurso de que conoce el Tribunal Constitucional" 7 , pues "[n] uestra Carta Fundamental establece un control de constitucionalidad en abstracto mediante el recurso de inaplicabilidad de que conoce el Tribunal Constitucional" 8 . Para él, las referencias a lo concreto en la letra del artículo 93 No 6, leídas a la luz de la ley que la desarrolla, inciden, no en el fondo, sino en la admisibilidad de la acción: "La consideración del caso concreto al que debe aplicarse el precepto impugnado es un requisito de admisibilidad que el tribunal debe considerar con laxitud atendiendo a la fundamentación del recurso y los antecedentes acompañados y que sirve, además, para aclarar la contradicción que justifica la inaplicabilidad"?.

Por su parte, el Tribunal Constitucional, al justificar sentencias de inaplicabilidad, obra de modo que queda patente que interpreta la inaplicabilidad en sentido abstracto, a la manera de la Corte Suprema, como una cuestión puramente normativa en virtud de la cual debe pronunciarse acerca de la eventual contradicción entre el precepto legal impugnado y alguna disposición constitucional, de preferencia alguna que contenga un derecho fundamental. No suele haber en los fallos del Tribunal Constitucional una apreciación morosa de los hechos sobre los que versa la gestión de fondo pendiente ni tampoco explícitas declaraciones por las que, defendiendo la constitucionalidad abstracta de un precepto legal, al mismo tiempo pronuncie la inconstitucionalidad de su aplicación a un caso concreto. Al contrario, la actitud general de este tribunal ha sido la que se lee en el considerando décimo de la sentencia rol No 2156, de noviembre de 2012: "Que la declaración de inaplicabilidad por inconstitucionalidad puede entenderse como expresiva de una legislación o regulación negativa para una

7 Rodríguez (2013), p. 32.

8 Rodríguez (2013), p. 32.

9 Rodríguez (2013), p. 32. 
situación específica -la que se juzga en la gestión pendiente-, en términos que impide al tribunal de la instancia aplicar el precepto impugnado, sin perjuicio de su atribución soberana para resolver el asunto de conformidad al ordenamiento jurídico no cuestionado"10. El tribunal constitucional, como demuestran estas palabras, realiza tan claramente un control abstracto con efectos particulares que se convierte, también en sede de inaplicabilidad y no sólo en la de inconstitucionalidad, en un legislador negativo. Una doctrina como ésta, así de explícita, es escasa, pero, como se ha dicho, impregna de hecho muchas sentencias tanto estimatorias como desestimatorias de inaplicabilidad, por lo que la derogación del artículo 80 de la constitución aparece hasta aquí como exclusivamente orgánica, como una reforma en grado mínimo, que conservó el recurso de inaplicabilidad, pero desplazando su conocimiento a un tribunal especializado.

La reforma sería más intensa si, además del órgano, el constituyente hubiera sustituido la función, lo que ocurriría si la reforma hubiera establecido un control con efectos particulares, pero no ya abstracto, sino verdaderamente concreto, que es la segunda alternativa que se anticipó más arriba. Así lo cree la doctrina mayoritaria. Por ejemplo, cree Francisco Zúñiga que el antiguo recurso de inaplicabilidad por inconstitucionalidad que consagraba el ya derogado artículo 80 de la constitución fue sustituido por la nueva acción de inaplicabilidad por inconstitucionalidad del actual artículo 93 No 6 . A su juicio, esto constituiría el paso desde una "[...] configuración anterior a la reforma constitucional de 2005 [en que] la acción de inaplicabilidad [sic], para la doctrina jurisprudencial de la Corte Suprema, poseía un carácter jurídico y abstracto, meramente doctrinario, toda vez que la inconstitucionalidad es un asunto de derecho [a una situación en que] [1] a acción de inaplicabilidad configurada en el actual artículo 93 No 6 de la constitución, responde en puridad a un esquema nuevo y distinto del tradicional [al esquema], de un control concreto de constitucionalidad, en el cual los aspectos de hecho de la gestión judicial en que incide, resultan clave para construir el juicio de legitimidad constitucional de la norma impugnada, sometiendo el proceso de constitucionalidad a una inevitable casuística"11.

También el Tribunal Constitucional ha hecho explícitamente declaraciones en este sentido, sin perjuicio de que, luego y eventualmente, el esquema justificativo de

10 Cfr. S.T.C. rol No 2156 (20/11/12), considerando décimo.

11 ZúNiga (2010), p. 19. 
la sentencias las desmienta. A modo ejemplar, valga lo que el tribunal, dice aquí12, citando a la doctrina: "El precepto revela que la magistratura constitucional no está compelida a la mera comparación abstracta de dos normas de diverso rango, para desentrañar su incompatibilidad, sino que en el instituto de la inaplicabilidad por inconstitucionalidad" comparecen tres elementos de cotejo necesarios para su decisión; a saber: la norma constitucional, el precepto legal cuya inaplicación se solicita y -lo más específicamente decisivo- el examen particular acerca de si 'en ese caso, la aplicación del precepto cuestionado pudiera generar efectos opuestos a la finalidad implícita de aquella...". Por eso, continúa el tribunal, "puede advertirse que hay preceptos legales que pueden estar en perfecta consonancia con la carta fundamental y, no obstante ello, ser inaplicables a un caso particular, precisamente porque en la particularidad de ese caso, la aplicación de una norma legal objetada es contraria a los efectos previstos por la norma constitucional"13.

El tercer nivel de intensidad de la reforma tiene que ver con el control abstracto con efectos generales, y no hay que demorarse mucho en él porque es claro que la institución de la acción de inconstitucionalidad del artículo 93 No 7 es del todo nueva respecto del régimen del antiguo artículo 80 , aunque sólo lo sería por los efectos generales y no por el su carácter abstracto, el que, como se ha demostrado, estaba presente desde entonces y, según algunos, aún pervive.

Y tampoco habría que hacer mención exhaustiva al cuarto nivel, que sería el de un control concreto con efectos generales que constituye un absurdo que, esperablemente, nadie ha lucubrado a propósito del control de constitucionalidad de las leyes, pero que, no obstante, aparece perfilado en el control de constitucionalidad de los autos acordados que se practica de acuerdo al artículo 93 No 2 de la constitución, el cual, según el artículo 94, produce efectos derogatorios. Cualquiera sea el sentido de la expresión "derogados" que emplea este precepto, es obvio que la sentencia estimatoria de una cuestión de constitucionalidad contra autos acordados tiene alcance general, a pesar de que en la sentencia rol No 2243-2013, para rechazar una cuestión de esta clase, el fallo pareciera entretenerse en consideraciones de control concreto, tal como el voto de minoría se lo reprocha ${ }^{14}$. El absurdo de la práctica de un control concreto con efectos generales

12 STC rol $529(09 / 11 / 06)$, cons. $15^{\circ}$.

13 Cfr. Ríos (2005), pp. 77 y 78.

${ }_{14}$ En esta cuestión se pedía la declaración de inconstitucionalidad del precepto del Auto Acordado sobre Tramitación y Fallo del Recurso de Protección de Garantías Constitucionales que autoriza a las Cortes para suspender a los funcionarios públicos renuentes de cumplir lo resuelto por ellas, en relación con la suspensión 
(si derogatorios o anulatorios, queda por verse) deriva de que, en último término, viola flagrantemente la igualdad ante la ley al extender a todos los casos lo que es peculiar de uno solo. Es por ello que los efectos derogatorios de la sentencia son siempre indiciarios -aunque sólo indiciarios- de una modalidad abstracta de control.

La discusión acerca de su intensidad, por ende, queda centrada en si la reforma constitucional del año 2005 que derogó el artículo 80 reemplazó tanto la función como el órgano llamado a desplegarla, o sea, le otorgó al Tribunal Constitucional competencia para ejercer un control realmente concreto con efectos particulares o si, conservando la antigua función de control abstracto, cambió solamente el órgano al que se le atribuye. De los trabajos preparatorios bien poco puede sacarse con certeza ${ }^{15}$, aunque puede sostenerse que hubo un relativo consenso en que el nuevo artículo 93 № 6 introducía un cambio funcional que instauraba un efectivo control concreto de constitucionalidad de las leyes, lo que quedaría probado por el tenor que finalmente adquirió la disposición, pues el reproche de ser contrario a la constitución se refiere en él a la aplicación del precepto y no al precepto mismo. Con todo, según ese estricto tenor, lo que pronuncia el Tribunal Constitucional, al acoger la acción, no es exactamente una declaración de inconstitucionalidad de la aplicación del precepto legal impugnado, sino una declaración de inaplicabilidad de ese precepto, sutileza que cobra importancia a la hora de preguntarse sobre qué cosa recae el juicio de inconstitucionalidad en que se funda esta declaración de inaplicabilidad, pues, como se verá, la declaración de inaplicabilidad puede sustentarse en la inconstitucionalidad del precepto mismo o en la inconstitucionalidad de la sentencia que lo aplica.

A la luz de todo esto, cabe responder la inquietud sobre la naturaleza de la reforma negando que haya pruebas suficientes de que sólo se haya mantenido el control abstracto del recurso de inaplicabilidad o de que sólo haya sido reemplazado

de que fue objeto un alcalde que, contra lo dispuesto por la corte, procedió a ordenar la demolición de un edificio. En el punto 4 del voto de minoría, se dice: "En primer lugar, esta Magistratura ha definido que la facultad que tiene para controlar autos acordados no es un control concreto, sino que abstracto, pues de acogerse el requerimiento, la norma se entiende derogada. Por lo mismo, no afecta sólo a quienes interpusieron la acción de inconstitucionalidad [...] Lo anterior es relevante, porque aquí no estamos juzgando si el alcalde desconoció o no la orden de la Corte de no demoler un edificio. Lo que estamos juzgando es si se ajusta a la Constitución la norma que permite que una Corte de Apelaciones, en base a un auto acordado, sin que haya ley que la habilite, pueda disponer la suspensión de una autoridad electa por el pueblo". Considerando 4, voto de minoría, STC rol No 2243 (3/09/13).

15 Cfr. Pfeffer (2005). 
por un control concreto, y la razón de ello es que ambas tesis están parcialmente en lo correcto, lo que aparece claro si se mira el subsistema de control represivo de la ley en su conjunto.

La doctrina estándar suele afirmar que el control de inaplicabilidad es concreto, pero que el Tribunal Constitucional no ha sido plenamente fiel a este modelo $^{16}$, al mismo tiempo que añade una crítica al modelo sobre la base de la mezcla irrazonable que el modelo haría entre controles abstractos y concretos. Se repite que "el constituyente derivado del 2005 cometió importantes errores en el diseño de la acción de inaplicabilidad, particularmente en su articulación con la acción de inconstitucionalidad y el control preventivo, lo que ha dificultado la distinción entre el control 'concreto' (propio de la acción de inaplicabilidad) y los controles 'abstractos' (propios de los controles preventivos y la acción de inconstitucionalidad)" 17 . En efecto, para la doctrina estándar carecería de sentido la exigencia de una sentencia estimatoria de inaplicabilidad, que sería concreta, como requisito para la admisibilidad de un requerimiento de inconstitucionalidad abstracto, del mismo modo que carecería de sentido o sería de interpretación difícil la disposición contendida en el artículo 84 No 2 de su ley orgánica (reiteración del artículo 51 inciso final) que impone al tribunal la declaración de inadmisibilidad de una acción de inaplicabilidad cuando "la cuestión se promueva respecto de un precepto legal que haya sido declarado conforme a la Constitución por el Tribunal, sea ejerciendo el control preventivo o conociendo de un requerimiento, y se invoque el mismo vicio que fue materia de la sentencia respectiva”. Este sello de constitucionalidad constituye el caso inverso, aunque igualmente extraño, pues, si antes se exigía un control aparentemente concreto como requisito para un control abstracto, ahora se exige la ausencia de una declaración abstracta de constitucionalidad de un precepto como requisito para la admisibilidad de un control concreto del mismo ${ }^{18}$.

No obstante, si se admite que el artículo 93 No 6 contiene dos acciones, una de inaplicabilidad impropia o abstracta, que permite, como demuestra la práctica del Tribunal Constitucional, el ejercicio de un control abstracto, al mismo tiempo que una de inaplicabilidad propia o concreta, según demuestra la doctrina y las declaraciones en este mismo sentido hechas por el tribunal, entonces la

16 Cfr. ZÚNIGA (2010).

17 Couso y Coddou (2010), pp. 389 y ss.

18 En un sentido diferente al aquí expuesto, cfr. Garrote (2012). 
pretendida incoherencia deja de existir. Aquí, habría un principio de congruencia cuyo lema sería que sólo lo abstracto impacta en lo abstracto. Entonces, si está considerado en ese numeral ( $93 \mathrm{No} 6$ ) un control abstracto, es razonable que el examen abstracto con efectos generales practicado sobre un precepto legal durante el control preventivo obligatorio o facultativo, o bien conociendo una acción de inconstitucionalidad, no deba repetirse cuando el vicio invocado para fundar una inaplicabilidad sea nuevamente la mera incompatibilidad normativa entre los mismos preceptos, uno legal y uno constitucional, que el tribunal ya desestimó. Por la misma razón, si el tribunal determinó, gracias a puras consideraciones abstractas, que un precepto legal debía ser inaplicado a una gestión pendiente, es igualmente razonable que esta declaración abstracta con efectos particulares pueda ser considerada, entre los requisitos de admisibilidad de la acción de inconstitucionalidad, como un prudente filtro para la derogación (o anulación) con efectos generales del precepto impugnado. En cambio, la declaración abstracta de constitucionalidad de un precepto, preventiva o represiva, no es óbice para la posterior declaración de inaplicabilidad concreta de ese mismo precepto, actitud que el tribunal de hecho ya ha asumido ${ }^{19}$, pues, siendo una abstracta y otra concreta, jamás el precepto impugnado podrá estar afectado por el mismo vicio, identidad de vicio que es una exigencia impuesta por la ley. En esa misma línea, el que, por otra parte, el tribunal no esté imperado de declarar siempre la inconstitucionalidad después de una sentencia estimatoria de inaplicabilidad se explica perfectamente si se tiene en cuenta que esta inaplicabilidad pudo ser efectivamente concreta, conforme a las peculiaridades de un caso, de modo que nada justifica su extensión general a todos los demás casos, en los que es dable pensar que dichas peculiaridades no se dan.

De todos modos, en el Tribunal Constitucional no está ausente la intuición, que no pasa de allí, de la existencia de las dos acciones de inaplicabilidad, la propia o concreta y la impropia o abstracta, como queda de manifiesto en esta sentencia por la que debe pronunciarse sobre la suspensión de la licencia de conducir por acumulación de infracciones que prescribe el artículo 207, letra b), de la Ley No 18.290, Ley de Tránsito. El requirente de inaplicabilidad alega que esta disposición viola los preceptos constitucionales que aseguran el respeto

19 Cfr. STC rol No 1246 (1/12/2009). Cons. 6º a 8º. Allí se denomina impropiamente "cosa juzgada constitucional" al usualmente llamado "sello de constitucionalidad". La razón para admitir la declaración de inaplicabilidad de un precepto legal declarado constitucional es precisamente la distinción entre el control abstracto y el concreto que formula en el considerando octavo. 
al principio del non bis in idem, pues la sanción de suspensión de la licencia por acumulación de infracciones se impone como un castigo añadido a los recibidos por las infracciones acumuladas, sin que este nuevo castigo se funde en alguna nueva conducta. El tribunal, por su parte, comienza razonando así:

Que, para que la acción de inaplicabilidad pueda prosperar, debe estarse siempre en presencia de un conflicto de constitucionalidad, esto es frente a una contradicción directa, clara y precisa, entre determinado precepto legal que se pretende aplicar en el caso concreto, y la propia Constitución, la cual en algunas ocasiones podrá brotar con claridad del solo texto del precepto legal cuestionado y en otras emergerá de las peculiaridades de su aplicación al caso concreto ${ }^{20}$.

El tribunal cree, entonces, que por la vía de la inaplicabilidad debe examinarse si el precepto legal "que se pretende aplicar al caso concreto" contradice o no algún precepto constitucional, y queda claro que, con tales palabras, para el tribunal lo inconstitucional no es la aplicación del precepto, sino el precepto aplicable, vale decir, está obrando sobre la base de que el control es puramente normativo o abstracto. Sin embargo, intuyendo que las cosas pueden no ser así, agrega que la contradicción puede "brotar" de dos modos: "del solo texto del precepto legal cuestionado" o "de las peculiaridades de su aplicación al caso concreto". En suma, lo que el tribunal vislumbra es que puede haber un doble fundamento de la inaplicabilidad, uno abstracto y uno concreto, y, lamentablemente, no infiere, como cabe hacer desde allí, que, por tanto, hay dos causas de pedir diferentes que, como tales, son elementos que identifican dos acciones diferentes.

Como sea, luego de distinguir entre una modalidad abstracta y otra concreta de la supuesta única inaplicabilidad, el Tribunal Constitucional termina nuevamente confundiéndolas en el considerando décimo octavo:

Que tanto la prevención general como la prevención especial, perseguidas por el legislador constitucional y legal, reafirman el criterio de que el objetivo intimidatorio del Estado como asimismo el objetivo específico de prevenir la reincidencia resultan afectados por la aplicación de una sanción duplicada por un mismo hecho, atendida la naturaleza y condiciones específicas del caso concreto $^{21}$;

Luego de una larga argumentación, que sigue las razones ya ofrecidas en otras causas para declarar inaplicable el precepto legal cuestionado por estimarlo en sí

20 Rol No 2896 (25/08/16) (considerando primero).

21 STC, cit. (considerando 18\%). 
mismo contrario a la constitución, resulta que, sin que se sepa cómo, los argumentos atienden ahora a "la naturaleza y condiciones específicas del caso concreto".

Durante el año 2016 y todo el 2017, el Tribunal Constitucional ha continuado practicando, por la vía de la inaplicabilidad, un control abstracto de constitucionalidad de la ley, en particular de la ley penal, razonando en cada caso, para acoger o rechazar la acción, sobre si los preceptos impugnados violan o no los límites que la constitución le impone al ius puniendi. En las numerosísimas sentencias que se pronuncias sobre la inaplicabilidad del artículo $1^{\circ}$ de la Ley $N^{\circ} 18.216$ (en cuanto prohíbe aplicar penas sustitutivas por la comisión de ciertos delitos, como los relativos al control de armas) y del artículo 196 ter de la Ley No 18.290 (en cuanto hace imperativo el cumplimiento efectivo de la pena de un año de privación efectiva de la libertad en ciertos cuasidelitos cometidos con ocasión de la conducción de vehículos) el Tribunal Constitucional razona reprochando o confirmando la constitucionalidad del contenido mismo del precepto, declarando la incongruencia o la congruencia del precepto mismo (y no su concreta aplicación a un caso) frente a la constitución ${ }^{22}$.

A este respecto, es oportuno subrayar la importancia que, para una razonable justificación de la declaración de constitucionalidad abstracta de un precepto legal como eventual obstáculo para su declaración de inaplicabilidad, tiene la distinción entre el control obligatorio y el control facultativo de las leyes y, dentro del control obligatorio, entre el que recae sobre leyes orgánicas constitucionales y el que lo hace sobre leyes interpretativas de la constitución. En los dos casos de control facultativo abstracto de la ley que son reconocidos por la doctrina estándar -el preventivo abstracto del artículo 93 No 1 y el represivo abstracto del artículo 93 No 7- la declaración de constitucionalidad pronunciada por el tribunal es la consecuencia de un razonamiento explícito en torno a un vicio alegado por el legitimado activo; en estas sentencias, el Tribunal Constitucional tiene la oportunidad de ofrecer una motivación suficiente que, al negar lugar al requerimiento preventivo o a la acción represiva, confirma que el vicio abstracto alegado no es tal, de manera que es fácil establecer una eventual congruencia entre estas sentencias y las resoluciones que declaran inadmisibles las acciones de

22 A modo de muestra: STC rol No 3280-16 (18/07/17), una de las muchas sentencias de la misma fecha e idéntico tenor que acogían las acciones contra el artículo $1^{\circ}$ de la Ley No 18.216. Por rechazarlo, a modo de muestra, STC 3257-16 (18/07/17). Como se ve, con la misma fecha aparecen acogidas y rechazadas acciones análogas, pero lo importante es que en ellas el tipo de justificación es claramente abstracto. En cuanto a la impugnación de la Ley No 18.290, a modo de muestra, por acogerlo parcialmente STC 2983-16 $(13 / 12 / 16)$ y, por rechazarlo STC rol No 2936-15 (20/10/16). 
inaplicabilidad impropia que pretenden reiterar una discusión ya zanjada sobre el mismo vicio.

Pero cuando el control es obligatorio, hay que separar lo que acontece con las leyes interpretativas de lo que ocurre con las leyes orgánicas constitucionales. El artículo 49, inciso 4, de la Ley No 17.997, referido al control preventivo obligatorio, dispone que "la resolución deberá ser fundada si se tratare de una ley interpretativa de la Constitución", por lo cual puede establecerse con menos dificultad si la petición de inaplicabilidad posterior pide o no un pronunciamiento sobre un posible vicio que pudo haberse ya descartado en la declaración previa de constitucionalidad.

Cuando se trata de leyes orgánicas constitucionales, hay que seguir haciendo distinciones, pues puede darse el caso que, durante la discusión del proyecto, algunos parlamentarios hayan hecho reservas de constitucionalidad, en los términos del artículo 48, inciso $3^{\circ}$ de la Ley No 17.997. En tal escenario, la resolución del tribunal que practica el control preventivo obligatorio será fundada y, como en los demás, podrá, más o menos, determinarse si el vicio alegado en la inaplicabilidad impropia o abstracta es el mismo vicio que el juzgador ya descartó.

Lo grave ocurre cuando no se han hecho esas reservas de constitucionalidad, pues la sentencia que declara constitucionales los preceptos orgánicos constitucionales de una ley no está fundada ni hace referencia a vicio alguno por cuyo descarte se reafirme la constitucionalidad del precepto. En este caso, el Tribunal Constitucional emite una declaración de constitucional prima facie, en la cual sólo indica que, por ejemplo, tales y cuales preceptos orgánicos constitucionales son constitucionales, sin que, atendida la naturaleza de este control, tenga la oportunidad de fundamentar explícitamente ese juicio de constitucionalidad. Se trata de una declaración de constitucionalidad prima facie porque, del hecho de no referirse a vicio alguno, no puede razonablemente inferirse que descarta todo los vicios posibles. Los preceptos orgánicos constitucionales, en estas circunstancias, declarados constitucionales por el Tribunal Constitucional, en modo alguno impiden el ejercicio de una acción de inaplicabilidad; no lo impiden, por su naturaleza, respecto de la inaplicabilidad propia o concreta (en virtud de la congruencia que exige ir sólo de lo abstracto a lo abstracto), pero tampoco lo impiden respecto de la inaplicabilidad impropia o abstracta, pues, para que la inadmisibilidad tenga sentido, es condición indispensable que la sentencia de constitucionalidad se haya referido, para descartarlo, a algún vicio. Es imposible que una acción de inaplicabilidad impropia o abstracta se refiera al mismo vicio de una sentencia de constitucionalidad si ésta no alude a vicio ninguno. Esta es, 
entonces, una situación diferente a la que regula el artículo 51 de la Ley No 17.997, que impide impetrar un requerimiento preventivo después que el tribunal ya se haya pronunciado, igualmente de manera preventiva, por la constitucionalidad de los proyectos de ley en cuestión, pues en este caso, hay una congruencia entre controles abstractos.

Como ya se dijo, en la acción de inaplicabilidad impropia o abstracta el objeto sometido a control es el propio precepto legal y no su aplicación a un caso concreto. Con esta interpretación, el tenor del artículo 93 No 6 no es infringido, pues sería un error creer que la impugnación concreta ataca la aplicación mientras que la abstracta no lo hace. En verdad, ambas, la concreta y la abstracta, atacan la aplicación de un precepto, sólo que, en la concreta, dicho ataque es único y directo, o sea, lo único que se reprocha es la aplicación de un precepto, mientras que en la abstracta el reproche a la aplicación de un precepto es derivado, porque es la consecuencia necesaria del reproche contra la validez del precepto mismo, el que, por inválido, debe dejar de ser aplicado por los jueces. La cosa pedida de esta acción de inaplicabilidad impropia o abstracta es la inaplicación del precepto para decidir la gestión pendiente en que puede incidir, es decir, la prohibición de usarlo como premisa de la decisión, y la causa de pedir, vale decir, el fundamento último de la acción, es, en el fondo, la invalidez del precepto en cuestión. Se trata de una acción contra un precepto legal anulable por la que se pide, no su anulación, sino su inaplicación, para que después, por la vía de la inconstitucionalidad, se anule definitivamente. En sentido lato, la inaplicabilidad, a la espera de la declaración de inconstitucionalidad, funciona como una especie de cautela, y por eso sus efectos son sólo inter partes.

Hay una congruencia entre el carácter que asume el tribunal como legislador negativo singular cuando ejerce el control abstracto y el carácter abstracto de la ley. Se sabe que la ley ha sido entendida como conteniendo enunciados generales y abstractos. Es general en tanto "opere frente a todos los sujetos de derecho, sin distinción" 23 y es abstracta, lo que "puede definirse como la "generalidad en el tiempo" y que consiste en prescripciones destinadas a valer indefinidamente y, por tanto, formuladas mediante "supuestos de hecho abstractos»" 24 , o sea, cuando el supuesto de hecho de la norma no describe con precisión los rasgos singulares de un hecho. La sentencia que resuelve una acción de inaplicabilidad

23 Zagrebelsky (2003), p. 29.

24 ZagrebelsKy (2003), p. 29. 
impropia o abstracta es la de un legislador porque coincide con el legislador en su carácter abstracto, aunque no lo sea por su carácter general (contrario a los efectos particulares de la sentencia) y es negativo, obviamente, porque procura que la sentencia no se ciña a un precepto legal.

En cuanto a las demás modalidades del control, hay que sostener que es concentrado, ya que, tratándose de su invalidez, hay buenas razones de diseño institucional para impedir que los tribunales ordinarios o especiales lo lleven a cabo; represivo, considerando que la causa de pedir es la invalidez de un precepto que, por ende, ha de estar vigente; y es facultativo porque, para iniciar el proceso, se precisa la actividad ante el Tribunal Constitucional de las partes de una gestión o del juez que la conoce.

\section{LA ACCIÓN DE INAPLICABILIDAD POR}

\section{INCONSTITUCIONALIDAD PROPIA O CONCRETA}

La doctrina estándar sostiene que la derogación del artículo 80 y la incorporación a la constitución del artículo 93 No 6 dio paso, desde un régimen de control puramente abstracto, a una acción esencialmente caracterizada por su carácter concreto, expresado en la sustitución del antiguo tenor según el cual la Corte Suprema podía "declarar inaplicable para esos casos particulares, todo precepto legal contrario a la constitución" por el nuevo tenor conforme al cual el Tribunal Constitucional puede declarar "la inaplicabilidad de un precepto legal cuya aplicación [...] resulte contraria a la Constitución”. El carácter concreto de la nueva acción quedaría manifiesto en la designación del objeto sobre el cual recae el control. La doctrina estándar señala que, antes, el control recaía en un precepto legal, lo que confería al control un carácter abstracto, mientras que ahora el control recae, ya no en el precepto legal mismo, sino en su aplicación a un caso concreto. La inconstitucionalidad reclamada no sería ya la del precepto legal sino la de su aplicación.

En la sección anterior se ha defendido la idea de que una correcta interpretación de esta disposición constitucional debe arribar a la conclusión de que en ella no se ha excluido el control abstracto, el cual sobrevive en la acción de inaplicabilidad por inconstitucionalidad impropia, pero que, además, y junto a ésta, se alza otra acción de inaplicabilidad, la acción de inaplicabilidad por inconstitucionalidad propia, que, si bien reviste el aspecto de concreción que la doctrina estándar le atribuye, es descrita erróneamente por esta doctrina, al menos, en tres de sus características: el control que esta acción pone en movimiento no es represivo sino 
preventivo; este control no tiene por objeto un precepto legal sino una sentencia judicial; y, finalmente, este control, siendo de equidad constitucional correctiva, no incide en el de la acción de inconstitucionalidad.

Por cierto, de estas tres características la principal es la que concierne al objeto sobre el cual recae el control. El tenor del artículo 93 No 6 es fuente de confusiones al respecto, ya que parece señalar que el control recae sobre un precepto legal, aunque su inconstitucionalidad sólo quedaría demostrada al examinar su comportamiento en un caso concreto. Por eso, la doctrina estándar, luego de flotar un poco al garete, ha terminado por recalar en la idea implícita de que, más que una cierta fuente del derecho o en una norma (el precepto legal o una norma en él contenida), lo que en realidad se impugnaría sería un acto jurídico: el acto de aplicar un precepto. ¿Cómo entenderlo de otro modo cuando se refuerza la tesis de que lo verdaderamente inconstitucional es la aplicación del precepto y no el precepto mismo, el que puede estar simultáneamente dotado de una prístina inocencia constitucional?

No obstante, aunque bien encaminada en lo que a la inaplicabilidad propia se refiere, la doctrina estándar no dio el paso que era, a todas luces, necesario: si a la letra del artículo 93 № 6, lo inconstitucional es la aplicación de un precepto, entonces la fuente del derecho controlada es precisamente aquella que es producida mediante el acto de aplicación, es decir, la sentencia judicial que aplica dicho precepto legal. Y, si el propósito del recurrente no es dejar sin efecto una cierta aplicación ya consumada sino evitar que ella se produzca, queda claro que el control es preventivo, puesto que se pretende evitar que nazca a la vida del derecho una sentencia inconstitucional. La acción de inaplicabilidad por inconstitucionalidad propia da lugar, así, a un control preventivo de constitucionalidad sobre sentencias judiciales, definitivas o interlocutorias, dictadas por tribunales ordinarios o especiales $^{25}$. Más aún: si la gestión pendiente en la que incide el precepto legal puede, incluso, ser una mera actuación dentro del proceso, como una simple citación

25 Un atisbo incrédulo del control preventivo de constitucionalidad de las sentencias está detrás de la "casación constitucional adivinatoria” por la que se pregunta Aldunate. Cfr. Aldunate (2007). p. 42. A este respecto, hay que enfatizar la necesidad de una lectura unificada de la inaplicabilidad y de la casación, puesto que en ambos casos hay o es admisible que haya un control concreto fundado en la equidad constitucional y en ambos se alza una discusión acerca de su carácter abstracto o concreto. Sobre esto último, Cfr. TARUFFo (2005). También Manuel Núñez Poblete ha entrevisto el control preventivo de constitucionalidad de las sentencias, aunque concibiéndolo como recursivo y sin formularlo explícitamente. Cfr. NúNÉEZ (2012) pp. 191 y ss. 
a absolver posiciones ${ }^{26}$, debe ampliarse el objeto del control a toda resolución judicial en que pueda darse aplicación a un precepto legal, incluyendo, entonces, a los decretos y a los autos que deciden sobre actuaciones para las cuales cierto precepto legal puede ser decisivo, aunque dicha ampliación fuera, por motivos prácticos, inconveniente. En suma, si bien son correctas las sentencias del Tribunal Constitucional que declaran inadmisibles las acciones de inaplicabilidad dirigidas contra sentencias judiciales, ellas lo son, no porque se impugnen sentencias, sino porque estas sentencias se impugnan represivamente, es decir, porque se dirigen contra sentencias ya pronunciadas: son inadmisibles por su oportunidad, no por su objeto. El control de constitucionalidad represivo y concreto de las sentencias judiciales -la proscripción de interpretaciones inconstitucionales de un precepto legal- no compete al Tribunal Constitucional, sino a los tribunales ordinarios y, particularmente, a la Corte Suprema cuando conoce de un recurso de casación en el fondo. Esto hace del control de constitucionalidad de sentencias judiciales un control mixto, puesto que, cuando es preventivo, lo practica el Tribunal Constitucional y, cuando es represivo, lo practica un tribunal ordinario.

No debiera sorprender el carácter preventivo de constitucionalidad de las sentencias, análogo (pero no idéntico) al de la ley. En efecto, según la doctrina estándar, entre las varias funciones del Tribunal Constitucional, la más importante es la de ejercer el control de constitucionalidad de ciertas fuentes del derecho, $\mathrm{y}$, de las varias fuentes del derecho que la constitución somete a su control, una de las más relevante es la ley. Como se sostiene, ésta queda sometida a controles preventivos y controles represivos. Los controles preventivos de la ley están consagrados en los numerales $1^{\circ}$ (control obligatorio de leyes interpretativas de la constitución y de leyes orgánicas constitucionales, además de algunos tratados) y $3^{\circ}$ (control facultativo de toda clase de ley), mientras que los controles represivos se encuentran en los numerales $6^{\circ}$ (acción de inaplicabilidad por inconstitucionalidad impropia) y $7{ }^{\circ}$ (acción de inconstitucionalidad). Si se examinan los casos de control preventivo, puede verse que en el numeral $1^{\circ}$ se señala claramente que el objeto del control es la ley porque dice expresamente "control de constitucio-

26 Cfr. STC rol No 2381 (20/08/13). Allí se debatió sobre la posibilidad de la diligencia de absolución de posiciones en un litigio seguido ente el Tribunal de Defensa de la Libre Competencia. La resolución que, aplicando el artículo 29 del D.L. No 211, que remite al artículo 385 del Código de Procedimiento Civil, cita a absolver posiciones, es un decreto, mientras que, si se solicita reposición, la resolución que resuelve esta reposición es una sentencia interlocutoria que resuelve un incidente del juicio estableciendo derechos permanentes en favor de las partes. La inaplicabilidad pudo ser deducida para evitar que se dictara aquel decreto o esta sentencia interlocutoria. 
nalidad de las leyes", mostrando el carácter preventivo al exigir que el control se practique "antes de su promulgación". En cambio, el tenor del numeral $3^{\circ}$ no señala explícitamente que el objeto del control sea la ley; no dice que el Tribunal debe resolver las cuestiones sobre constitucionalidad de las leyes sino que debe "[r]esolver las cuestiones sobre constitucionalidad que se susciten durante la tramitación de los proyectos de ley [...]". Pero no hay constitucionalista que pueda sostener otra cosa que lo que aquí, sin ser explícito, es meridianamente claro: aunque no se diga que el objeto del control es la ley y se mencione sólo la oportunidad en que se practica, es obvio que el objeto del control es precisamente el proyecto de ley durante cuya tramitación puede deducirse el requerimiento. La redacción dada a este enunciado se explica, evidentemente, porque ella permite regular a un mismo tiempo el objeto (preceptos legales) y la oportunidad (preventivo) del control.

Algo análogo ocurre con el enunciado del artículo 93 No 6. En la acción de inaplicabilidad por inconstitucionalidad, la constitución exige para la procedencia de la acción de inaplicabilidad que la gestión judicial se encuentre pendiente, lo que equivale, en el contexto judicial, a lo que en el contexto legislativo se expresa como "durante la tramitación" del proyecto de ley. Aunque el 93 No 6 no habla explícitamente de "proyecto de sentencia" como sí lo hace el 93 No 3 con la mención hecha a los "proyectos de ley", es claro que en ambos casos se exige que se encuentre pendiente, en tramitación, el procedimiento destinado a la producción de una determinada fuente formal del derecho, que en un caso es la ley y, en el otro, la sentencia definitiva o interlocutoria (o incluso, eventualmente, un auto o un decreto), y si en uno el procedimiento deja de estar en tramitación cuando se ha promulgado la ley, en el otro deja de estar pendiente cuando se ha dictado la sentencia o la resolución. La estructura es la misma porque la oportunidad para la práctica del control es también la misma: en ambos el control es preventivo, o lo es de la ley o lo es de la sentencia, "durante la tramitación" de una u otra. Nuevamente desde su autonomía semántica, la falta de una expresa mención al "proyecto de sentencia" abona la tesis de que en este enunciado normativo hay dos acciones, una para impugnar abstracta y represivamente preceptos legales y otra para impugnar concreta y preventivamente sentencias judiciales ${ }^{27}$. Hay que

27 Considerando el amparo español, no puede sorprender que se practique control de constitucionalidad sobre las sentencias. De allí a determinar que también es posible un amparo preventivo hay un solo paso. Y sólo uno más para extender este control preventivo de los enunciados que constitucionalizan derechos a todos los enunciados constitucionales en los cuales se puede fundar una inaplicabilidad. El Tribunal 
aclarar, eso sí, que cuando se habla de "proyecto de sentencia" no se quiere decir que haya una especie de borrador parecido al proyecto de ley que es sometido a tramitación legislativa. El proyecto de sentencia es, más bien, el proyecto de una premisa que se contendría en la sentencia si en ella se aplicara el enunciado normativo contenido en el precepto legal cuya inaplicación se pide, pues dicho enunciado legal se jurisdiccionaliza al pasar a integrar la parte considerativa de la sentencia que lo aplica. Lo controlado preventivamente es aquel proyecto de considerando de la sentencia en que se usa el contenido de un cierto precepto legal para fundar la decisión; se controla preventivamente la parte considerativa, pero no la parte resolutiva de la sentencia.

Otra prueba de que el objeto del control es la sentencia, es la deferencia debida por el Tribunal Constitucional a las otras autoridades con que intersecta el ejercicio de sus funciones. Cuando ejerce el control de constitucionalidad, la deferencia la tiene siempre con respecto al autor de la fuente que es objeto del control, y si hay tal deber de deferencia respecto del juez a cargo de la gestión pendiente ${ }^{28}$, esto ocurre, claramente, porque el objeto controlado es la resolución judicial que éste juez produce. Si el fundamento de la deferencia es el respeto del ámbito de competencia de otras autoridades, la deferencia debida al juez prueba que lo respetado no es el ámbito de competencia del legislador (como ocurre en el control abstracto, singular o general) sino el ámbito de competencia del juez.

Una consecuencia de esto es que la declaración de inaplicabilidad propia de un precepto legal, a diferencia de lo que ocurre con su declaración de inaplicabilidad impropia, no impide que este precepto legal declarado inaplicable, aunque suene paradójico, sea efectivamente aplicado en la sentencia que resuelve la gestión pendiente. Esto prueba que en este caso el control es preventivo de la sentencia

Constitucional ha negado que la inaplicabilidad sea un amparo, pero lo ha hecho, no para objetar que su objeto sea una sentencia, sino para negar que sea represivo o recursivo: "Que, asimismo, el requerimiento de inaplicabilidad no puede ser utilizado como un mecanismo de amparo destinado a proteger situaciones de supuesta injusticia que se puedan haber producido durante la tramitación de un juicio. Este exige una contradicción, en el caso concreto, de un precepto legal con la Constitución; pero en una gestión donde ese precepto pueda ser aplicado. Como este Tribunal ha señalado, la acción de inaplicabilidad no es una vía procesal idónea para impugnar resoluciones judiciales en orden a revocar, enmendar, revisar, casar o anular éstas, ya que la guarda del imperio de la ley en el conocimiento, juzgamiento y ejecución de lo juzgado en general y de la sustanciación en particular, de las causas civiles y criminales, corresponde exclusivamente a los tribunales creados por ley a través de las vías procesales previstas en las leyes de enjuiciamiento". STC rol No 1576 (16/12/10). Cons. 35. Para la interpretación de la inaplicabilidad como un amparo imperfecto, Cfr. Cazor y Pica (2009).

28 Cfr. Martínez (2015), pp. 237 a 270. 
y no represivo de la ley, lo que queda manifiesto en una sentencia que resuelve sobre la inaplicabilidad del artículo $4^{\circ}$ de la Ley $\mathrm{N}^{\circ} 19.531^{29}$. Este precepto legal liberaba a quienes hubieran gozado de descanso de maternidad o de licencia por accidente del trabajo del requisito de haber servido el cargo judicial durante al menos seis meses para tener derecho a ciertos beneficios económicos. La sentencia declaró inaplicable este precepto legal para resolver la acción de protección por la cual un juez que padecía una enfermedad catastrófica -ni maternidad ni accidente del trabajo- solicitaba que se lo liberara igualmente de ese requisito. Al resolverse la acción de protección, es obvio que la Corte de Apelaciones de Valparaíso ${ }^{30}$, para extenderle al ministro recurrente la exención del requisito mencionado, debió aplicar el precepto declarado inaplicable, sólo que procediendo a una interpretación extensiva del mismo. Vale decir, el objeto de la declaración de inaplicabilidad no fue el precepto mismo, como si se lo hubiera recortado a tijeras de la ley, sino su interpretación declarativa o estricta, o, mejor aún, lo que fue declarado inconstitucional de modo preventivo fue la parte considerativa de la sentencia que pudiera eventualmente contener una interpretación declarativa o estricta del mismo precepto legal.

Cuando el control es concreto, entonces, el objeto controlado es la resolución que lo aplica, la que, normalmente, será una sentencia. Si esto no lo ve la doctrina estándar es porque muchos de los problemas que la aquejan derivan de la falta de precisión en las nociones de control concreto y control abstracto que ella utiliza. Ya es un lugar común repetir, siguiendo el tenor de la constitución, que a tales controles los distingue su objeto, que, en el caso del control concreto, sería la aplicación del precepto legal y en el del control abstracto sería, en cambio, el precepto legal mismo. Ya se ha probado que, si bien es correcta la tesis de que hay dos objetos diferentes, debe, sin embargo, reprocharse a la doctrina estándar el modo asimétrico con que identifica esos dos objetos, pues se compara, por una parte, una fuente del derecho (precepto legal) y, por otra, una actuación jurídica

29 STC rol No 1801-2010 (12/04/11). El autor debe hacer la prevención ética de haber tenido la calidad de abogado patrocinante del Ministro de la Corte de Apelaciones de Valparaíso en cuyo favor fue interpuesta la acción de inaplicabilidad.

30 La Corte Suprema, resolviendo la apelación deducida por la Corporación Administrativa del Poder Judicial contra la sentencia de la Corte de Apelaciones de Valparaíso se pronunció por la revocación al estimar que el precepto legal citado ya había sido aplicado por la Corporación, por lo que, estando consumada la aplicación, no cabía que la sentencia del Tribunal Constitucional cambiara el estado de cosas. Se trata de una sentencia abiertamente infundada que simplemente desconoció el instituto mismo de la acción de inaplicabilidad. Cfr. "Gómez con Corporación Administrativa del Poder Judicial", rol No 4518-2011. 
(aplicación), cuando lo que corresponde es que se comparen fuentes del derecho entre sí o actuaciones entre sí: o bien el precepto legal y la sentencia o bien el acto de producir la ley y el acto de aplicar la ley.

En esta misma línea, cabe señalar que la diferencia entre los controles concreto y abstracto no radica en que el primero sea un control practicado sobre la interpretación de un precepto legal y el segundo sea un control que recaiga sobre el precepto mismo, puesto que, en ambas situaciones, el control se dirige a una cierta interpretación del precepto legal, porque es gracias a la interpretación del precepto que se hace posible fijar su contenido jurídico para que, luego, el tribunal pueda contrastarlo con el de la constitución. La interpretación, que es el modo por el cual se conoce el contenido de un enunciado normativo, es, entonces, ineludible en ambos casos. De esto, se desprende que la distinción entre el control abstracto y el control concreto radica, más bien, en alguna diferente modalidad que adquiere la interpretación del precepto legal en una y otra circunstancia.

Podría decirse, del modo más lato posible ${ }^{31}$, que el control es abstracto cuando no remite a caso alguno, mientras que es concreto si, en cambio, tiene como referencia un caso. Pero esta afirmación se ve aquejada por la debilidad del presupuesto, no probado, conforme al cual es posible practicar la interpretación de un precepto legal sin remisión a caso alguno. Esto, como puede anticiparse, depende de la noción de "caso" que se tenga a la vista. A veces, cuando se quiere hablar de la inaplicabilidad como un tipo de control concreto, se dice que ella queda vinculada a un caso concreto, donde lo concreto del caso pareciera indicar lo contrario de caso abstracto. Habría, por ende, en ambos tipos de control, referencia a un caso, sólo que, en el primero, el caso sería concreto y, en el otro, sería abstracto. Lo concreto y lo abstracto de un caso equivaldrían a la distinción entre un caso real, efectivamente dado, del cual conoce el juez del fondo, y un caso imaginario o puramente hipotético, puesto por una parte o por el propio Tribunal Constitucional de manera puramente esquemática, sin las particularidades infinitas que separan aquello que es real de aquello que es sólo posible. Así como es ilusorio pretender el conocimiento de un precepto legal sin interpretarlo, sería

31 Corresponde a la teoría del derecho la elucidación más precisa del fundamento de esta distinción entre control concreto y control abstracto como derivada de la distinción más amplia entre la interpretación concreta y la interpretación abstracta. En este problema - universalismo y particularismo jurídico- convergen numerosas cuestiones iusfilosóficas (teoría del leguaje, metafísica de las normas, epistemología jurídica, lógica deóntica, teoría de la acción, teoría del razonamiento práctico, teoría de la interpretación y otros), problemas que, por supuesto, no deben ser tratados en un artículo de dogmática constitucional como éste, pero que serán abordados en el futuro sobre la base de los artículos ya publicados y citados más abajo. 
ilusoria, también, la idea de un proceso de interpretación que omita cualquier referencia a un caso real particularizado o a un caso posible esquematizado.

Esto quedaría probado, además, con un argumento jurisprudencial y otro normativo. El Tribunal Constitucional, cuando practica el control preventivo (que sería siempre abstracto) suele idear situaciones (casos hipotéticos esquematizados) que le permiten formular sus sentencias interpretativas, conforme a las cuales se declara la constitucionalidad de un precepto en el entendido de que sea interpretado de un cierto modo, y lo mismo suele hacer cuando rechaza las acciones de inconstitucionalidad fundado en que el precepto impugnado admite alguna interpretación conforme a la constitución. Por eso, fue acertado el argumento del Tribunal Constitucional por el que rechazó la objeción que reprochaba a un requerimiento preventivo abstracto el fundarse en las consecuencias posibles de un proyecto de ley y no en la inconstitucionalidad del sus preceptos mismos, dado que "el control de constitucionalidad [...], supone [...] contrastar los preceptos que se reprochan con las disposiciones constitucionales que se suponen infringidas, lo que también importa efectuar ciertos razonamientos fácticos e hipotéticos, lo que es propio de toda interpretación constitucional, desde que las disposiciones siempre se encuentran dirigidas a personas concretas a quienes en definitiva afectarán [...]". Por otra parte, argumentando ahora desde las propias normas constitucionales, a propósito del control de constitucionalidad de los autos acordados, que aparece regulado como un control abstracto, la propia constitución admite como legitimada activa a la parte en una gestión pendiente, lo que brinda un argumento normativo que hace explícita la posibilidad de referirse a un caso real (el de la gestión en que incidirá el auto acordado) para la práctica de un control abstracto. En términos más sencillos: el caso está siempre presente en el control de constitucionalidad de los numerales 6 y 7 del artículo 93, sea como un supuesto de hecho del enunciado normativo impugnado (caso abstracto esquematizado), sea como gestión pendiente (caso concreto particularizado).

Hay que distinguir, por consiguiente, entre el hecho, el caso y el supuesto de hecho. El hecho es eso que tiene lugar en el mundo, en su dimensión existencial, práctica e inabarcable en su singularidad. Los jueces no conocen directamente los hechos, sino mediante esas reconstrucciones de los hechos en que se escogen algunos de sus rasgos y, convertidos en casos, se los presentan al juez como relevantes. El supuesto de hecho es la descripción general y abstracta de un caso posible; el hecho es un acontecimiento real en el mundo; el caso es una descripción que escoge rasgos del hecho y se los presenta al juez como relevantes. El control de constitucionalidad es abstracto cuando consulta si es constitucional asignar, en 
una ley, tal consecuencia jurídica a tal supuesto de hecho. El control es concreto cuando consulta si es constitucional que una sentencia subsuma un caso, o sea, un asunto sometido a la decisión de un juez, en un cierto supuesto de hecho descrito en una ley. En este evento, la cuestión será de mera legalidad si el problema es de simple subsunción, o sea, de la determinación de la ley aplicable; en cambio, será una cuestión de verdadera constitucionalidad cuando, siendo subsumible un caso en el supuesto de hecho de un precepto legal y no siendo objetable la constitucionalidad de las consecuencias jurídicas que se consiguen para ese supuesto de hecho, con todo, estas consecuencias revisten tales características para el peculiar caso pendiente que, aplicárselas, resulta inconstitucional. Por cierto, el caso ha de estar caracterizado de modo tal que una de sus características haga constitucionalmente relevante lo que carecía de relevancia para el solo precepto legal. Por eso se trata, aquí, no de objetar las consecuencias jurídicas a un supuesto de hecho (control abstracto) ni de discutir si el caso es subsumible en ese mismo supuesto de hecho (cuestión de mera legalidad), sino de impedir, por razones constitucionales, una subsunción que posible pero constitucionalmente inconveniente.

Para la adecuada comprensión del control concreto que define a la acción de inaplicabilidad propia o concreta hay que evitar confundir, sin embargo, los casos especiales, peculiares, que siguen siendo casos, o sea reconstrucciones narrativas de hechos singulares, con estos mismos hechos singulares. Los casos especiales que autorizan el control concreto siguen siendo las narraciones de acontecimientos reales del mundo, vaciados de todo lo que los distingue de todos los demás hechos singulares. Por eso, varios hechos singulares puedan ser descritos como el mismo caso especial, siempre que en ellos esté presente aquella característica que es relevante para el juez y que fue imprevista por el legislador cuando configuró el supuesto de hecho de la norma, el caso abstracto. Esto permite justificar la práctica de que la misma declaración de inaplicabilidad se extienda a otros hechos singulares que, conforme a sus propiedades fácticas relevantes, puedan ser descritos como el mismo caso especial, sin que, por ello, el control concreto mute en abstracto.

$\mathrm{Al}$ conocer una acción de inaplicabilidad, por ende, el Tribunal Constitucional debe definir, en primer lugar, si la acción deducida es una inaplicabilidad propia o impropia, según se ataque el precepto mismo aplicable o la futura sentencia que lo aplica a un caso especial. Si se trata de una acción de inaplicabilidad impropia, probado que la gestión pendiente es subsumible en el supuesto de hecho del precepto legal impugnado, deberá proceder al examen de la eventual contradicción normativa entre el precepto legal y la constitución, a la luz de los fundamentos abstractos ofrecidos en el requerimiento y deberá acogerla si la oposición denun- 
ciada efectivamente existe. $\mathrm{Si}$, a la luz del requerimiento, el tribunal concluye que la apelación por parte del interesado a ciertas peculiaridades del caso demuestra que la inaplicabilidad deducida es propia o concreta, debe proceder primero a un control abstracto y luego a un control concreto. Esto es así porque el control concreto supone que el precepto legal en sí mismo, abstractamente, respeta la constitución, de manera que si el precepto legal es constitucional, sólo entonces el Tribunal podrá pasar a conocer de la inaplicabilidad propia, examinando cómo es que las peculiaridades del caso impiden que la sentencia futura que resuelva este caso aplique el precepto legal señalado, y, conforme a esto, podrá acoger o rechazar la acción. Sin embargo ¿qué debe hacer el tribunal en el evento de que se deduzca una inaplicabilidad concreta y, tras el examen preliminar abstracto, detecte que el precepto es, ya en sí mismo, inconstitucional? Ante todo, como las acciones impropia y propia son incompatibles (si el precepto es abstractamente inconstitucional no puede ser concretamente inconstitucional), el tribunal debe rechazar la acción de inaplicabilidad propia porque ella, precisamente, supone la constitucionalidad del precepto, lo que el tribunal ya descartó. Pero, ¿puede de todos modos pronunciar la inaplicabilidad impropia sin infringir el principio de pasividad del tribunal? Por supuesto que, para las partes, lo razonable es que, siendo acciones incompatibles, deduzcan las acciones de inaplicabilidad impropia y propia (en ese orden) con carácter subsidiario una de la otra. Pero ¿y si no lo hacen, entre otras cosas, porque no las distinguen adecuadamente? La respuesta puede hallarse en el artículo 88 de la ley orgánica del tribunal: "Excepcionalmente y por razones fundadas, el Tribunal podrá declarar la inconstitucionalidad de las normas cuestionadas basado únicamente en fundamentos constitucionales distintos a aquellos que han sido invocados por las partes en la litis". Esta regla parece pensada para permitir al tribunal invocar como violada una disposición constitucional diferente a las señaladas por el requirente, pero nada impide utilizarla también con este propósito, que es congruente con su facultad para declarar la inconstitucionalidad de oficio. En suma, el pronunciamiento de la inaplicabilidad impropia cuando el requerimiento se funda en la inaplicabilidad propia dependerá, entonces, de un juicio de valor del tribunal acerca de la conveniencia de que este precepto inconstitucional continúe su camino hacia su derogación.

Para ilustrar este punto, cabe leer la sentencia que resuelve sobre la inaplicabilidad del artículo 434 del código penal (que castiga los actos de piratería) ${ }^{32}$, cuya

32 STC rol No 549-2006 (30/03(07). 
constitucionalidad fue consultada por el tribunal oral de Concepción y que, adicionalmente, fue objeto de una acción de inaplicabilidad. El proceder consignado en el considerando décimo quinto de esta sentencia fue casi perfecto. En efecto, el tribunal ejecutó allí, primero, un control abstracto que lo llevó a descartar la inconstitucionalidad del precepto ("[...] hasta ahora, se ha analizado la compatibilidad de la norma objetada con la Constitución en un cotejo abstracto, para concluir que la interpretación que se le da es conciliable con la ley fundamental"). Sólo después de haber establecido la validez material de ese enunciado se dispuso a llevar a cabo el control concreto ("Sin embargo, la acción de inaplicabilidad tiene por objeto verificar si la aplicación de un precepto legal [...] resulta contraria a la constitución [...]"), para terminar también desechando, de este segundo modo, en el considerando décimo octavo, la acción de inaplicabilidad ("Que, en el caso sublite, no se identifica la circunstancia distinta, especial o excepcional, que pudiera derivar en una aplicación de la norma objetada que resulte contraria a la constitución”). Un defecto terminológico afecta, con todo, a esta sentencia: la inadvertencia del hecho de que el control abstracto es igualmente un control de aplicación, aunque referido a la aplicación de preceptos inválidos, por lo que no puede, salvo por economía lingüística, denominar control de aplicación sólo al concreto, es decir, al control de aplicación de preceptos inequitativos. Hay que enfatizar que, en este ejemplo, el Tribunal Constitucional debió practicar ambos controles, el concreto después del abstracto, dado que su actividad fue movida por un requerimiento judicial, pero, si sólo hubiera existido el requerimiento de parte, hubiera sido erróneo que el tribunal se sintiese obligado a practicar un control concreto después de haber descartado la inconstitucionalidad abstracta, sin que la acción deducida fuese una acción de inaplicabilidad propia que tuviese como causa de pedir la inequidad de la sentencia que aplique el precepto a alguna circunstancia especial del caso. Como, en este caso, el requirente sólo había impugnado abstractamente el precepto, si sólo hubiera existido tal requerimiento de parte y no el judicial, el tribunal tendría que haber cerrado sin más la sentencia desestimando la acción de inaplicabilidad impropia.

Otro ejemplo más reciente en que el Tribunal Constitucional despliega verdaderamente un control concreto es el de un caso en que rechaza la acción de inaplicabilidad deducida contra un precepto de la Ley No 18.290 que impone un año de cumplimiento efectivo de la pena ${ }^{33}$. Como se dijo en la sección ante-

33 STC rol No 2897-15 (4/07/17). 
rior, en todos estos casos, tanto para acoger como para rechazar las acciones, el tribunal razona abstractamente. Sin embargo, a pesar de que no se resta a seguir razonando así, en la STC rol No 2897-15, de 4 de julio de 2017, el rechazo se debió a la práctica de un control concreto que consideró el hecho particular de que la condenada a dicha pena efectiva ya la había cumplido por imputación del tiempo en exceso que pasó en prisión preventiva. Cualesquiera fueren los juicios sobre la constitucionalidad de este precepto, las circunstancias de hecho justificaban el rechazo del requerimiento.

Finalmente, en cuanto a la función que despliega en este caso el Tribunal Constitucional conforme a la descripción hecha del control concreto, hay evidentemente una analogía entre la función que cumple el control concreto de constitucionalidad de la ley que se encauza por la acción de inaplicabilidad propia y aquella función correctiva de la ley que se atribuye a la equidad desde los tiempos de Aristóteles ${ }^{34}$. En ambos casos se procura remediar la inevitable incapacidad de una ley que es abstracta para regular adecuadamente todos los casos concretos que surjan en la vida social ${ }^{35}$. La constatación en la que se fundan ambas instituciones es que en ocasiones los jueces deben resolver casos subsumibles en el supuesto de hecho de una ley, pero que poseen además ciertas peculiaridades relevantes que tornan poco razonable la aplicación a ellos de una interpretación estricta de esa ley. Así, puede ocurrir que un precepto legal cualquiera no se oponga en abstracto a disposición constitucional alguna o no sea, también en abstracto, manifiestamente injusto, pero que, aplicado a un caso concreto, revele un aspecto inconstitucional o de manifiesta injusticia que haga inconveniente su aplicación en una sentencia, sentencia cuya dictación en tales términos hay que, por ende, evitar. En los dos casos de control abstracto (inaplicabilidad impropia e inconstitucionalidad) lo que se somete a juicio es la ley misma (su interpretación abstracta), mientras que en el de la inaplicabilidad propia o concreta, lo sometido a juicio sigue siendo el caso de que el juez conoce ${ }^{36}$.

\footnotetext{
34 Un anticipo del control de constitucionalidad como equidad, aunque esbozado de otra manera, se encuentra en RabBi-BaLdi Cabanillas, Renato (1999), pp. 445 a 486.

35 Una articulación diferente entre ambos controles, que no llega a identificar dos acciones diferentes de inaplicabilidad pero que no es incompatible con la aquí expuesta, es la que se plantea en BronfMAN, Alan (2011), pp. 243 y ss. Refiriendo al principio de separación de poderes, critica el modelo de control privado que representa el control concreto.

36 El control de constitucionalidad como equidad correctiva para los casos chileno y español se ha explicado en SALAS (2015), pp.1579 y ss. Por otra parte, las tesis sobre las cuales se sustenta la idea de constitucionalización de la equidad a partir del título preliminar del código civil, han sido esbozadas en SALAS (2015), pp. 95 y ss.
} 


\section{LA INCONSTITUCIONALIDAD GENERAL}

La tercera acción que forma parte de este subsistema de control de constitucionalidad es la acción de inconstitucionalidad consagrada en el artículo 93 No 7 de la Constitución ${ }^{37}$. Allí, se encomienda al Tribunal Constitucional: "Resolver por la mayoría de los cuatro quintos de sus integrantes en ejercicio, la inconstitucionalidad de un precepto legal declarado inaplicable en conformidad a lo dispuesto en el numeral anterior" 38 . Por consiguiente, es claro que la disposición sobre inconstitucionalidad está desde un inicio imbricada con la de la inaplicabilidad. A esta imbricación se refieren los artículos 93, 95 y 97 de la Ley No 17.997, Orgánica Constitucional del Tribunal Constitucional, a los que se remite el inciso 12 del artículo 93 de la Constitución.

En sede de inconstitucionalidad, el vínculo más intenso entre la inaplicabilidad y la inconstitucionalidad que establece la ley se halla en la regla del artículo 101: "La declaración de inconstitucionalidad de las normas legales cuestionadas deberá fundarse únicamente en la infracción de el o los preceptos constitucionales que fueron considerados transgredidos por la sentencia previa de inaplicabilidad que le sirve de sustento”. En palabras más sencillas, esta disposición señala que sólo pueden declararse inconstitucionales preceptos legales que hayan sido declarados inaplicables.

Tanto la resolución preliminar con que el Tribunal Constitucional inicia el proceso para declarar de oficio la inconstitucionalidad como el requerimiento por el que esta inconstitucionalidad es solicitada por quien goce de la legitimidad señalada en la Constitución deben ser fundados. Tratándose del requerimiento, el artículo 95 de la ley agrega que los requirentes "deberán fundar razonablemente la petición, indicando precisamente la sentencia de inaplicabilidad previa en que se sustenta y los argumentos constitucionales que le sirven de apoyo" y, por su parte, el artículo 97 No 2 consigna la siguiente como una causal de inadmisibilidad de la acción: "Cuando la cuestión se funde en un vicio de inconstitucionalidad distinto del que motivó la declaración de inaplicabilidad del precepto impugnado".

Los fundamentos de la declaración de inconstitucionalidad a que se refieren estos preceptos no pueden ser otros que aquellos argumentos que prueben la existencia de lo que ellos denominan un "vicio", pero, además, este vicio por el cual un precepto legal debe ser tenido por inconstitucional ha de ser el mismo

37 Cfr. Navarro, Enrique (2012).

38 Const. Pol. art. 93 No 7. 
vicio por el cual este precepto fue previamente declarado inaplicable. De esto cabe obviamente concluir que, si el vicio que motiva la inconstitucionalidad debe ser el mismo que motiva la inaplicabilidad, entonces ese vicio debe ser de la misma naturaleza en uno y otro caso, pues, de no serlo, mal podría ser calificado de "mismo vicio".

Para asegurarse que se trate del mismo vicio, el subsistema de control, según el artículo 101 de la ley, obliga a que la declaración de inconstitucionalidad se produzca a partir de los mismos preceptos constitucionales que se estimaron infringidos en la inaplicabilidad: "La declaración de inconstitucionalidad de las normas legales cuestionadas deberá fundarse únicamente en la infracción de el o los preceptos constitucionales que fueron considerados transgredidos por la sentencia previa de inaplicabilidad que le sirve de sustento". Así que lo que debe entenderse por vicio, tanto en la inaplicabilidad como en la inconstitucionalidad, depende de la específica relación entre un precepto legal singular y uno o varios preceptos constitucionales singulares, so pena de que, si, en el paso de la inaplicabilidad a la inconstitucionalidad, cambia alguno de los dos términos de la relación, jamás podrá hablarse de un mismo vicio para ambas. Pero, además, si el vicio consiste en una infracción que el precepto legal inaplicado hace del o de ciertos preceptos constitucionales, sólo podrá considerarse el mismo vicio si se trata en ambos casos de la misma clase de vicio, es decir, de la misma clase de infracción, de manera que no basta que se produzca una infracción de un mismo precepto legal frente al mismo precepto constitucional, sino que la infracción, hay que repetirlo, debe ser también la misma. Entonces, ¿cómo es posible que la declaración de inaplicabilidad acuse el mismo vicio, o sea, la misma infracción constitucional -una infracción de la misma clase y, dentro de esa misma clase de infracciones, exactamente la misma- que una declaración de inconstitucionalidad?

La conexión sólo es posible si la causa de pedir de ambas acciones es la misma. La causa de pedir es el fundamento de la acción, la justificación que sostiene la acción, las alegaciones jurídicas básicas en favor de la acción. Cuando la ley se refiere a que el requerimiento de inconstitucionalidad debe ser razonablemente fundado, está indicando la necesidad de identificar la causa de pedir de la acción. Pero si entre los fundamentos de la acción se distingue, como hace la doctrina procesal actual ${ }^{39}$, entre los fundamentos y la fundamentación de la acción, puede ahondarse más diciendo que cuando las reglas de procedencia de estas acciones

39 Cfr. De La Oliva (2005), p. 69. 
hablan, por una parte, de los argumentos y, por otra, del vicio, está distinguiendo entre la fundamentación y el fundamento de la acción. El vicio es el fundamento, los argumentos son la fundamentación, y la causa de pedir tiene que ver con el primero.

Se ha probado que la cosa pedida en la inaplicabilidad es la inaplicación, en una sentencia judicial ordinaria, de un precepto legal determinado, mientras que la cosa pedida en la inconstitucionalidad es la "derogación" del precepto legal impugnado. También se ha dicho que la causa de pedir de la inaplicabilidad puede ser una de dos, a saber, o bien la inequidad (obviamente concreta) de una sentencia judicial proyectada o bien la invalidez (obviamente abstracta) de un precepto legal vigente. Ahora se agrega que la causa de pedir de la inconstitucionalidad es el vicio (fundamento), cuya presencia debe ser justificada mediante argumentos razonables (fundamentación). Así, la conexión entre la inaplicabilidad y la inconstitucionalidad depende de que el mismo vicio o fundamento formen parte de la causa de pedir de una y otra, y esto ocurre sólo cuando los argumentos para pronunciar la inaplicabilidad, por su naturaleza abstracta, puramente normativa, se dirigen, no a establecer la inequidad, sino a probar la invalidez de un precepto legal que por su sola forma o su solo contenido infringen ciertas disposiciones constitucionales. En la inaplicabilidad impropia o abstracta, este control se hace a propósito de un caso concreto, pero no en referencia a las peculiaridades de ese caso, aunque lo que se busque, como cosa pedida, sea evitar que a ese caso concreto se le aplique un precepto legal inválido que, por inválido, tampoco debería ser aplicado a los demás.

En consecuencia, el requisito que exige para la declaración de inconstitucionalidad una sentencia estimatoria de inaplicabilidad es razonable si está limitado a la sentencia que declaró una inaplicabilidad impropia o abstracta. Este requisito carecería de toda razonabilidad si envolviera a las sentencias que pronuncian una inaplicabilidad propia o concreta, en las cuales el control es preventivo de inconstitucionalidad de una sentencia y no represivo de constitucionalidad de un precepto legal. De esto se deriva que la exigencia constitucional no descansa en el asunto puramente formal conforme al cual se requiere que el precepto impugnado de inconstitucionalidad haya sido declarado inaplicable, o sea, que exista una sentencia en que se haya otorgado la cosa pedida, sino que, más allá, exige que la cosa pedida se haya otorgado por una misma causa de pedir en uno y otro proceso. Esto justifica que el artículo 93 No 7 , una vez declarada la inaplicabilidad, otorgue competencia al Tribunal Constitucional para declarar de oficio la inconstitucionalidad del precepto lesivo y confiera acción pública con el mismo fin. 
En el control de admisibilidad, la tarea del tribunal no será sólo la de verificar que exista tal sentencia de inaplicabilidad; ni siquiera debe restringirse solamente a certificar que en el requerimiento se pida la declaración de inconstitucionalidad del mismo precepto legal respecto del mismo precepto constitucional sobre los que versa la sentencia estimatoria de inaplicabilidad. En el control de admisibilidad del tribunal debe calificar si la sentencia de inaplicabilidad invocada declara una inaplicabilidad propia o concreta o bien una impropia o abstracta, y confirmado que se trate de esta última, recién le cabe admitir a tramitación el requerimiento de inconstitucionalidad para que el tribunal declare si, en el fondo, finalmente, existe o no esta oposición abstracta entre el precepto legal y el constitucional en que se ha fundado la sentencia de inaplicabilidad impropia o abstracta. El tribunal puede, entonces, rechazar in limine ${ }^{40}$ el requerimiento en razón de la desemejanza entre los vicios reclamados, o sea, por falta de una causa de pedir idónea, lo que, remitiéndose al tenor de la ley, constituye una "falta de fundamento" incluso cuando el requerimiento cuente con una profusa fundamentación. Todo esto conduce a concluir que el examen de admisibilidad en la acción de inconstitucionalidad tiene también carácter sustantivo.

Una vez admitido a tramitación el requerimiento, cabe que el pleno del Tribunal Constitucional juzgue de todos modos, contra la opinión de la sala, que la sentencia de inaplicabilidad en que se funda el requerimiento de inconstitucionalidad tiene carácter concreto y, por esa razón, deberá desestimarlo. Y deberá desestimarlo incluso cuando el tribunal tenga motivos para creer que el precepto impugnado mediante ese requerimiento es abstractamente inconstitucional, ya que la constitución exige lo que en esta hipótesis no ha sucedido, a saber, que tal inconstitucionalidad abstracta haya sido previamente declarada, con efectos particulares, en una sentencia que declara la inaplicabilidad impropia del precepto. Si la declaración de inaplicabilidad impropia puede ser análogamente tratada como una cautela, entonces ha de haber congruencia entre la cautela y la decisión.

Por último, luego de constatada la congruencia adecuada entre el fundamento de la declaración de inaplicabilidad impropia y el fundamento del requerimiento, la acción de inconstitucionalidad deberá ser, en principio, acogida, pues, siempre en principio, no sería entendible que el Tribunal Constitucional discrepara consigo mismo considerando ahora como constitucionalmente válido exactamente lo mismo que antes creía ser un vicio de constitucionalidad. No es oportuno

40 Sobre las potestades de los jueces civiles, en este sentido extensible a la jurisdicción constitucional: Cfr. HunTER (2009). 
tratar aquí, sin embargo, el tema tan espinoso del régimen a que deben someterse los cambios jurisprudenciales del Tribunal Constitucional ni el carácter autovinculante de sus sentencias.

Publicada la sentencia que declara, con efectos generales, la inconstitucionalidad del precepto legal impugnado, éste, según el artículo 94, inciso $3^{\circ}$, de la constitución, se entiende "derogado" con efecto inmediato, es decir, sin efecto retroactivo. Hay que precisar, sin embargo, que el indudable efecto inmediato de la sentencia estimatoria de una inconstitucionalidad general puede coexistir con efectos diversos en el tiempo del precepto legal que, mediante ella, ha sido "derogado". Resulta claro que las relaciones jurídicas que acontecieren con posterioridad a la "derogación" del precepto legal no quedan bajo ningún respecto sometidas a él, pero bien puede ocurrir que el precepto "derogado", además del efecto inmediato del que fue privado por la sentencia que lo "derogó", pudo también tener efecto ultractivo, por el cual éste continúa rigiendo ciertas situaciones jurídicas aun después de su derogación (como ocurre con las leyes incorporadas a los contratos). Un juez puede perfectamente aplicar ultractivamente el precepto derogado para resolver los asuntos a que den lugar esas situaciones jurídicas, por lo cual resulta claro que, en estos casos, es igualmente admisible la declaración de inaplicabilidad de ese precepto que ya fue declarado inconstitucional. Por eso, no es correcto el criterio del tribunal que exige la vigencia de un precepto legal para declarar su inaplicabilidad ${ }^{41}$, pues lo que la constitución exige es que, para ser declarado inaplicable, el precepto deba ser previamente aplicable a la gestión, lo que no siempre calza con su simple vigencia. En este caso, el tribunal deberá admitir la acción de inaplicabilidad y discernir si se trata de una inaplicabilidad propia o impropia. Si es de la segunda clase, el tribunal deberá declarar la inaplicabilidad abstracta del precepto si se conforma a los mismos fundamentos que motivaron su previa declaración de inconstitucionalidad. En cambio, si se trata de una inaplicabilidad propia, el tribunal, supuesto que ahora entienda el precepto como ajustado abstractamente a la constitución, deberá examinar aquellas que en el requerimiento se han descrito como peculiares del caso y, a la luz de ellas, podrá perfectamente acoger o rechazar la acción. Como se ha dicho, esto supone

41 Cfr., por todas, STC rol No 756-2007 (12/11/2007), cons. 7º. En el Repertorio de su ley orgánica, referido a las doctrinas del tribunal sobre admisibilidad e inadmisibilidad, puede verse una enumeración exhaustiva de las sentencias que siguen este criterio erróneo. http://www.tribunalconstitucional.cl/leyorganica. (Visitado 23/08/ 2007). 
tratar, en otro lugar, el problema de los cambios de criterio en la jurisprudencia constitucional.

Como se ve, nada exige que, cuando el Tribunal Constitucional haya pronunciado la inconstitucionalidad de un precepto legal, deba siempre inclinarse por su efectiva declaración de inaplicabilidad. Lo que está en juego, nuevamente, es la relación entre las acciones de inaplicabilidad y la acción de inconstitucionalidad, sólo que, en esta circunstancia, la sentencia que ha pronunciado la inconstitucionalidad del precepto es anterior a la que debe decidir por su inaplicabilidad. La situación descrita es análoga a la del sello de constitucionalidad, respecto de la cual cabía preguntarse en qué sentido la sentencia de inaplicabilidad queda sujeta al contenido de una previa declaración abstracta de constitucionalidad. La diferencia, como es fácil notar, es que ahora el problema consiste en discernir los efectos que para la posterior sentencia de inaplicabilidad tenga una previa declaración abstracta, no de constitucionalidad, sino de inconstitucionalidad. Y la solución sigue el mismo camino: el Tribunal debe primero constar si la acción deducida es de una inaplicabilidad propia o de una impropia, y, de ser esta última, si el fundamento abstracto de la inaplicabilidad coincide con el fundamento abstracto de la sentencia que declaró la inconstitucionalidad del precepto impugnado. Si es así, la acción de inaplicabilidad impropia o abstracta debe ser acogida, so pena de violar la igualdad ante la ley. Pero si la justificación de la inaplicabilidad impropia o abstracta del precepto legal impugnado difiere de la justificación de la sentencia de inconstitucionalidad general o si la inaplicabilidad deducida es una inaplicabilidad propia, el Tribunal Constitucional, según el mérito de los argumentos y mientras no se regule el carácter autovinculante de sus sentencias, bien podría acoger o rechazar la declaración de inaplicabilidad propia o impropia de un precepto legal ultractivo que ya había sido declarado inconstitucional ${ }^{42}$.

\section{Conclusiones}

1. El Tribunal Constitucional ejerce un control abstracto de constitucionalidad de las leyes que puede ser preventivo o represivo y facultativo u obligatorio, por una parte, y un control concreto y preventivo de constitucionalidad de las sentencias o resoluciones judiciales. En el artículo 93 No 6 se contemplan ambas

42 Para una discusión sobre la inaplicabilidad de normas derogadas, Cfr. Henríquez (2012). 
clases de control, respectivamente, en la acciones de inaplicabilidad impropia o abstracta y propia o concreta.

2. En la inaplicabilidad concreta, el Tribunal Constitución controla preventivamente la constitucionalidad de una sentencia judicial y obra como juez de equidad correctiva. En la inaplicabilidad impropia controla la validez de un precepto legal y obra como legislador negativo singular.

3. La constitución y la ley ligan el control abstracto con el concreto cuando requieren una previa sentencia estimatoria de inaplicabilidad para la declaración de inconstitucionalidad. La ley lo hace cuando declara inadmisible una acción de inaplicabilidad dirigida contra un precepto declarado abstractamente constitucional. En ambos casos, el sentido del requisito depende de la distinción entre las inaplicabilidades propia e impropia. Si la inaplicabilidad es propia, no es obstaculizada por una previa declaración de constitucionalidad abstracta ni puede servir de requisito para una posterior declaración abstracta de inconstitucionalidad.

4. La declaración de constitucionalidad de preceptos legales orgánicos constitucionales, al no referirse a vicio alguno, jamás impide un nuevo control abstracto o un posterior control concreto de tales preceptos.

5. La inaplicabilidad impropia o abstracta, con efectos particulares, es inadmisible cuando con ella alega el mismo vicio descartado por una declaración previa de constitucionalidad abstracta. Esto es siempre posible cuando el control abstracto con efectos generales es facultativo (sea represivo o preventivo), cuando es obligatorio de leyes interpretativas de la constitución y cuando es obligatorio de leyes orgánicas constitucionales respecto de las cuales se ha hecho reserva de constitucionalidad.

6. El control de admisibilidad de una acción de inaplicabilidad o de una acción de inconstitucionalidad es sustantivo porque, entre otras cosas, busca verificar la congruencia entre los vicios alegados y los vicios ya examinados por el Tribunal Constitucional en sentencias previas en las que se pronuncia sobre constitucionalidades abstractas.

7. Es perfectamente posible acoger o rechazar la declaración de inaplicabilidad propia o concreta de un precepto legal ultractivo después de declarada su inconstitucionalidad y también es posible rechazar la inaplicabilidad impropia de este mismo precepto legal si el vicio alegado no es el mismo que motivó su derogación. Si tal vicio es el mismo, la inaplicabilidad debe rechazarse.

8. Esta perspectiva abre nuevas distinciones sobre las cuales examinar el juicio acerca de la legitimidad del control de constitucionalidad de las leyes. 


\section{BiBLIOGRAFÍA CITADA}

Aldunate, Eduardo (2007): "La reforma constitucional del año 2005 desde la Teoría del Derecho y la Teoría de la Constitución". En: Revista de Derecho Público, Vol. 69.

Atria, Fernando (2001): "Inaplicabilidad y coherencia. Contra la ideología del legalismo". En: Revista de Derecho, Universidad Austral, Vol. XII.

BRONFMAN, Alan (2011): "El carácter privado del proceso de inaplicabilidad por inconstitucionalidad”. XXXVII, 2011.

Cazor, Kamel y PiCA, Rodrigo (2009): “Tribunal Constitucional y control concreto en Chile: ¡evolución hacia un amparo imperfecto?”. En: Revista General de Derecho Constitucional No 7. http://www.iustel.com/v2/revistas/detalle_revista. asp?id_noticia $=4075568 \mathrm{~d}=1$ (Última visita: 19 de diciembre 2016).

Couso Salas, Javier y Coddou Macmanus, Alberto (2010): “La naturaleza jurídica de la acción de inaplicabilidad en la jurisprudencia del tribunal Constitucional: un desafío pendiente". En: Estudios Constitucionales Año 8, No 2.

De La Oliva, Andrés (2005): "El objeto del proceso y la cosa juzgada en el proceso civil". Civitas, Madrid.

GARROTE, Emilio (2012): "Cosa juzgada constitucional sui generis y su efecto en las sentencias del Tribunal Constitucional en materia de inaplicabilidad e inconstitucionalidad". Estudios Constitucionales Vol. 10, No 2, Santiago, 2012.

Henríquez, Miriam (2012): “¿Las normas derogadas pueden ser declaradas inaplicables por inconstitucionalidad?” En: SiLVA, María Pía y Henríquez, Miriam: "Derechos fundamentales y justicia constitucional. ¿Consolidación o reforma?”. Thomson Reuters, Santiago de Chile.

HunTER, Iván (2009): "El poder del juez para rechazar in limine la demanda por manifiesta falta de fundamento". En: Ius et Praxis, Año 15, № 2.

MarTínez Estay, José Ignacio (2015): "La deferencia del tribunal constitucional respecto del juez de la gestión pendiente en la cuestión de inaplicabilidad". Estudios Constitucionales, Año 13 No 1.

NAVARro, Enrique (2012): "La jurisprudencia del Tribunal Constitucional sobre la acción de inconstitucionalidad de la ley entre los años 2006 y 2012”. En: Revista de Derecho (Valparaíso) XXXIX, dic. 2012.

Nogueira, Humberto (2005): "El control represivo concreto y abstracto de inconstitucionalidad de leyes en la reforma de las competencias del tribunal 
constitucional y los efectos de sus sentencias". Estudios Constitucionales Vol. No $1,2005$.

NúÑEz PoBlete, Manuel (2012): "Desaplicación e inaplicación jurisdiccional de las leyes en Chile: ejercicio de la jurisdicción y control concreto de constitucionalidad". En: Revista de Derecho. Universidad Católica del Norte Año 19 , No 2.

Pfeffer, Emilio (2005): "Reformas constitucionales 2005. Antecedentes. Debates. Informes”. Edit. Jurídica de Chile, Santiago.

PICA, Rodrigo. (2010): "Control jurisdiccional de constitucionalidad de la ley en Chile: Los procesos de inconstitucionalidad y de inaplicabilidad por inconstitucionalidad de competencia del tribunal constitucional". Santiago, Ediciones Jurídicas de Santiago, 2010.

RABBI-BALDI CABANILLAS, Renato (1999): "La interpretación del derecho de acuerdo a «equidad» en la reciente jurisprudencia de la Corte Suprema de Justicia argentina”. En: Persona y Derecho No 40, año 1999 (Estudios en Homenaje al Prof. Javier Hervada).

Ríos, Lautaro (2005): “Trascendencia de la reforma constitucional en la fisonomía y las atribuciones del Tribunal Constitucional". En: Revista Estudios Constitucionales del Centro de Estudios Constitucionales de la Universidad de Talca, Año 3 No 1.

RodríGuez Grez, Pablo (2013): "Inconstitucionalidad en abstracto o en concreto". En: Revista Derecho Público Iberoamericano. Año I, No 2, abril.

SALAS, Ricardo (2015): "La equidad correctiva y el control de constitucionalidad de las leyes". En: VV. AA.: "Una filosofía del derecho en acción. Homenaje al profesor Andrés Ollero". Congreso de los Diputados, Madrid, 2015. pp. 1579 y ss.

SalaS, Ricardo (2015): "Nota sobre la constitucionalización de la interpretación legal". Revista de Filosofía y Ciencias Jurídicas, julio 2015. http://www.rfycj.cl. TARuffo, Michele (2005): El vértice ambiguo. Palestra, Lima, 2005.

Verdugo, Sergio (2009) "El sello de constitucionalidad de los preceptos legales declarados constitucionales en el control preventivo" en Revista de Derecho y Ciencias Penales No 13, pp. 57 y ss.

Zagrebelsky, Gustavo (2003): El derecho dúctil. Ley derechos, justicia. Trotta, Madrid. 
ZÚNIGA URBINA, Francisco (2010): Acciones de inaplicabilidad e inconstitucionalidad. Doctrina y jurisprudencia del Tribunal Constitucional sobre temas procesales. Editorial Abeledo Perrot Legal Publishing, Santiago de Chile.

\author{
NORMAS CITADAS \\ Constitución Política de la República
}

Art. $6^{\circ}$.

Art. 93 No 6.

Art. 93 No 7.

94

\title{
LEY No 17.997
}

Art. 48.

Art. 49.

Art. 50.

Art. 51.

Art. 93.

Art. 94.

Art. 95.

Art. 96.

Art. 97.

Art. 98.

Art. 99.

Arts. 100.

Arts. 101.

\section{Ley No 19.531}

Art. 4.

\author{
JURISPRUDENCIA CITADA \\ Tribunal CONSTITUCIONAL
}

STC rol No 529-2006. 
STC rol No 549-2006.

STC rol No 756-2007.

STC rol No 1246-2009.

STC rol No 1361-2009.

STC rol No 1576-2010.

STC rol No 1801-2010.

STC rol No 2156-2012.

STC rol No 2243-2013.

STC rol No 2936-15.

STC rol No 2897-15.

STC rol No 2983-16.

STC rol No 2896-2016.

STC rol No 3280-16 (muestra de conjunto de sentencias idénticas de 18/07/17).

STC rol No 3257-16 (muestra de conjunto de sentencias idénticas de 18/07/17).

\section{Corte Suprema}

Rol No 4518-2011. 